(2) Open Access Full Text Article

\title{
Personalized medicine and treatment approaches in hypertension: current perspectives
}

This article was published in the following Dove Press journal:

Integrated Blood Pressure Control

6 April 2016

Number of times this article has been viewed

\section{James Brian Byrd}

Division of Cardiovascular Medicine, Department of Medicine, University of Michigan, Ann Arbor, MI, USA

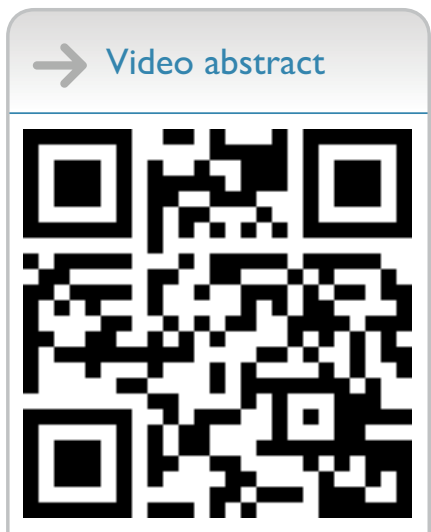

Point your SmartPhone at the code above. If you have a QR code reader the video abstract will appear. Or use: http://youtu.bef/Yyp3ivMMuc4
Correspondence: James Brian Byrd Division of Cardiovascular Medicine, Department of Medicine, University of Michigan, 20-209W North Campus Research Complex, 2800 Plymouth Road, Ann Arbor, MI 48I09-2800, USA

$\mathrm{Tel}+$ I 734998 799|

Fax + I 855230 I379

Email jbbyrd@umich.edu

\begin{abstract}
In the US, hypertension affects one in three adults. Current guideline-based treatment of hypertension involves little diagnostic testing. A more personalized approach to the treatment of hypertension might be of use. Several methods of personalized treatment have been proposed and vetted to varying degrees. The purpose of this narrative review is to discuss the rationale for personalized therapy in hypertension, barriers to its development and implementation, some influential examples of proposed personalization measures, and a view of future efforts.
\end{abstract}

Keywords: hypertension, blood pressure, personalized medicine

\section{Introduction}

More than a global epidemic, hypertension is in fact the leading risk factor for the global burden of disease, according to the World Health Organization. ${ }^{1}$ Current guidelines for the diagnosis and treatment of hypertension offer convenient heuristics for clinicians. However, these algorithms are not highly personalized to the pathophysiology of individual patients. Though greater personalization of hypertension treatment might be valuable, this "hypothesis" is too vague to be tested experimentally. What is meant by "personalization"? What type of value should personalization offer, and what costs are reasonable to buy greater personalization? Since no series of experiments could refute the possibility that some type of personalization would add some kind of value, attempts to understand personalized medicine must focus on specific, testable propositions. This narrative review highlights rationales for personalized hypertension care, influential personalization frameworks, limitations of these frameworks or their vetting, and future directions suggested by the current state of knowledge.

\section{Rationale for personalized medicine in the treatment of hypertension}

A logical starting point in considering personalized medicine in hypertension is to ask whether it is desirable. Francis Collins (director of the National Institutes of Health [NIH]) and Margaret Hamburg (former commissioner of the US Food and Drug Administration [FDA]) have written eloquently about the promise of personalized medicine. ${ }^{2}$ They highlight the way in which the genomic era has positioned medicine for successful personalization efforts. Since that article was written, genetic, genomic, transcriptional, and proteomic methods continue to evolve and to provide profound insights into pathophysiology. Turner et al elaborated additional thoughtful rationales for personalized medicine, specifically in the field of hypertension. ${ }^{3}$ The authors 
highlighted the intuitive appeal and the opportunity to benefit the individual patient maximally.

Personalized medicine for hypertension can be viewed in terms of predicting which drug will lower blood pressure (BP) most effectively in an individual. Another way to think of the problem is the inverse: personalized medicine to avoid patient-specific risks for adverse effects of drugs ${ }^{4}$ or drugs that predictably lack efficacy. Along these lines, well-described problems with adherence provide additional impetus to personalize the treatment of hypertension. Hypertension imposes an unparalleled burden of disease around the globe, ${ }^{1}$ yet adherence to antihypertensive medications is poor. ${ }^{5-7}$ A common problem, poor adherence is associated with a lack of improvement in cardiovascular risk. ${ }^{5}$ Though most adverse events due to antihypertensive medications are not life-threatening, these experiences can contribute to cardiovascular morbidity and mortality by virtue of decreasing adherence. The ability to predict adverse events or lack of efficacy in an individual patient would facilitate efforts to improve adherence.

\section{Barriers to personalized therapy for hypertension}

It is logical to assume that the rise of systems biology and the resulting novel biological insights will result in more personalized treatment of hypertension. However, there are significant barriers to overcome along the way. The translation of novel mechanistic insights into clinical algorithms depends upon painstaking and expensive clinical investigation. In addition, substantial resources will be required to overcome the natural tendency to do things as they have been done in the past.

\section{Costs of developing and evaluating personalized medicine approaches in hypertension}

A proposed personalization method would theoretically require a clinical trial to demonstrate persuasively benefit above current guideline-based therapy, though less stringent evidence might be acceptable. ${ }^{8}$ Science is an iterative process, and there will be failed personalized medicine efforts on the way to successful ones. To the extent that diagnostic methods predictive of response are developed in nonhuman species, the failure rate will be higher by virtue of species differences. To view a drug as "safe and effective" for all patients with a broadly defined indication, such as hypertension, is antithetical to personalized medicine. Consider, however, the position of a company developing a new drug for hypertension. What incentive exists for the company to define who will not benefit from the drug? In some situations, there may be a clear answer: a companion diagnostic test in which the company has a stake. In other situations, the answer is less clear. Despite hurdles, the field of oncology has demonstrated that with sufficient investment of resources, it is possible to implement personalized medicine approaches in the clinic (eg, GTPase KRas [KRAS]-mutation testing/ cetuximab treatment ${ }^{9}$ or HER2 testing/trastuzumab ${ }^{10}$ treatment). For the most part, the insights used to personalize oncologic treatment are currently inapplicable in hypertension. With rare exceptions, ${ }^{11,12}$ models of hypertension have not involved somatic mutations, which have been integral to oncology's personalized medicine successes.

\section{Barriers to adoption of personalized medicine in hypertension}

Successfully developing and vetting a novel approach to personalized treatment of hypertension does not ensure its widespread adoption. Law et al performed a seminal metaanalysis showing similar effectiveness of common antihypertensive medication classes in clinical trial populations. ${ }^{13}$ The investigators proposed a population-level "polypill" strategy for cardiovascular treatment based on age, rather than more personalized risk-factor analysis. Their argument is appealing, and has generated some misplaced skepticism of personalized medicine. Law et al's meta-analysis by no means precludes important, predictable individual differences in responsiveness to medication classes or susceptibility to adverse events. Indeed, their findings are compatible with continued strong interest in personalized treatment of hypertension. The most tractable form of personalized therapy for hypertension would not focus on forecasting distant future cardiovascular events (ie, improved risk-factor analysis). Rather, personalized treatment of hypertension would be most readily facilitated by the ability to anticipate drug response or adverse effects (responsiveness/tolerability). More successful BP lowering in individuals would in fact facilitate Law et al's goal of lowering the average BP in the population.

There is good reason to believe that predictable differences in responsiveness to antihypertensive medications exist. Common genetic variants affect the pharmacokinetics and pharmacodynamics of some antihypertensive drugs, eg, $\beta$-blockers ${ }^{14}$ and hydralazine. ${ }^{15}$ Moreover, there are distinct subsets of hypertensive pathophysiology. For example, at least some patients with primary hypertension have a decreased plasma volume compared to normotensive individuals. ${ }^{16}$ However, patients with mineralocorticoid-induced hypertension, eg, primary aldosteronism, have expanded plasma volume. This fundamental and reproducible physiologic difference would be expect to have implications for treatment response. However, convenient and accurate 
markers of plasma volume are not available in the clinic, with plasma renin activity (PRA) coming closest to this goal (in patients without concomitant heart failure). The field of hypertension awaits the development of clinically applicable phenotyping methods permitting strong inferences about pathophysiology and expected treatment response. The development of such tests depends upon the training of a cadre of sophisticated clinician-scientists interested in these issues. Cold Spring Harbor is now publishing a new journal focused solely on personalized medicine. Engagement from this premier research organization on this topic is likely to help stimulate rigorous research. In summary, therapeutic equivalence between various types of antihypertensive drugs cannot be presumed at the level of the individual, despite meta-analyses showing similar mean BP reduction and event reduction with different drugs at the population level.

\section{Influential approaches to personalizing drug therapy in hypertension}

The value of any specific approach to personalized medicine is not self-evident, but is a proposition to be tested. Previous attempts to personalize the treatment of hypertension illuminate potentially promising avenues, as well as pitfalls.

\section{Aldosterone measurement}

Personalized therapy is conditioned upon identifying a trait or group of traits differentiating the response of individual patients. Therefore, diagnostic testing is at the center of the personalized medicine movement. In 1954, scientists working in the chemical division of Merck \& Co reported the isolation of aldosterone, ${ }^{17}$ previously known as electrocortin. Conn reported the discovery of primary aldosteronism shortly thereafter - in $1955 .{ }^{18}$ By 1960 , Laragh et al had demonstrated that aldosterone was not consistently elevated in hypertension, ${ }^{19}$ and eventually primary aldosteronism was deemed rare. The development of the aldosterone-to-renin ratio described herein gave new life to the idea that primary aldosteronism is common. ${ }^{20}$ Aldosterone can increase in response to PRA, or due to primary aldosteronism. These situations would be treated differently, and thus measuring aldosterone in isolation is not an attractive method of personalizing antihypertensive medication therapy.

\section{Renin profiling}

PRA played a key evolutionary role in maintaining intravascular volume in an environment with scant sources of dietary sodium. PRA's role in the regulation of BP and response to medications was explored in seminal work by
Laragh, Sealey, and many colleagues over several decades. An excellent summary of some of the most important findings was published in 2011. ${ }^{21}$ An appealing and influential model of antihypertensive medication treatment informed by renin profiling emerged from this work. Egan et al compared renin profile-guided treatment to clinical judgment not informed by PRA in a randomized clinical trial in uncontrolled but treated hypertensive patients. The intention-to-treat analysis included 77 patients, and the findings indicated equal or better BP control using renin profiling. ${ }^{22}$ An additional randomized trial of renin profiling has been completed (https:// clinicaltrials.gov/ct2/show/NCT00834600); the results have not yet been published.

\section{Aldosterone-to-renin ratio}

PRA and aldosterone are regulated by several variables, and their relationship to each other may be more informative than either measurement alone. The ratio is used to diagnose primary aldosteronism, but is not recommended for widespread screening in patients with hypertension in US or European hypertension guidelines.

\section{Single-nucleotide polymorphism and haplotype approach to pharmacogenomics}

Seminal work done by Geller et al has elucidated a series of rare monogenic forms of hypertension. ${ }^{23-26}$ However, the contribution of common genetic variants, such as single-nucleotide polymorphisms (SNPs), to hypertension is complex and subtle. Genome-wide association studies have supported the prediction that SNPs have a small effect on physiology compared to rare disease-causing mutations. Therefore, attempts to predict response to medications using SNPs require large sample sizes and are unlikely to find effect sizes of clinical significance. After a series of small studies suggested that a particular insertion/deletion polymorphism in the $A C E$ gene was informative, the GenHAT study examined the relationship between the $A C E$ insertion/deletion polymorphism, treatment response in hypertension, and coronary heart disease. This study of 37,939 patients with hypertension demonstrated persuasively that there was no effect of insertion/deletion polymorphism on treatment response or coronary heart disease. ${ }^{27}$ Although many SNP-association studies have been performed in hypertension, SNP-association studies have come under criticism for poor reproducibility and potential for bias, ${ }^{28}$ and this mode of scientific inquiry has largely been abandoned. Table 1 highlights several genetic polymorphisms that have been intensively investigated as potential predictors of antihypertensive drug response. 
Table I Summary of candidate gene pharmacogenetics studies using antihypertensive medications

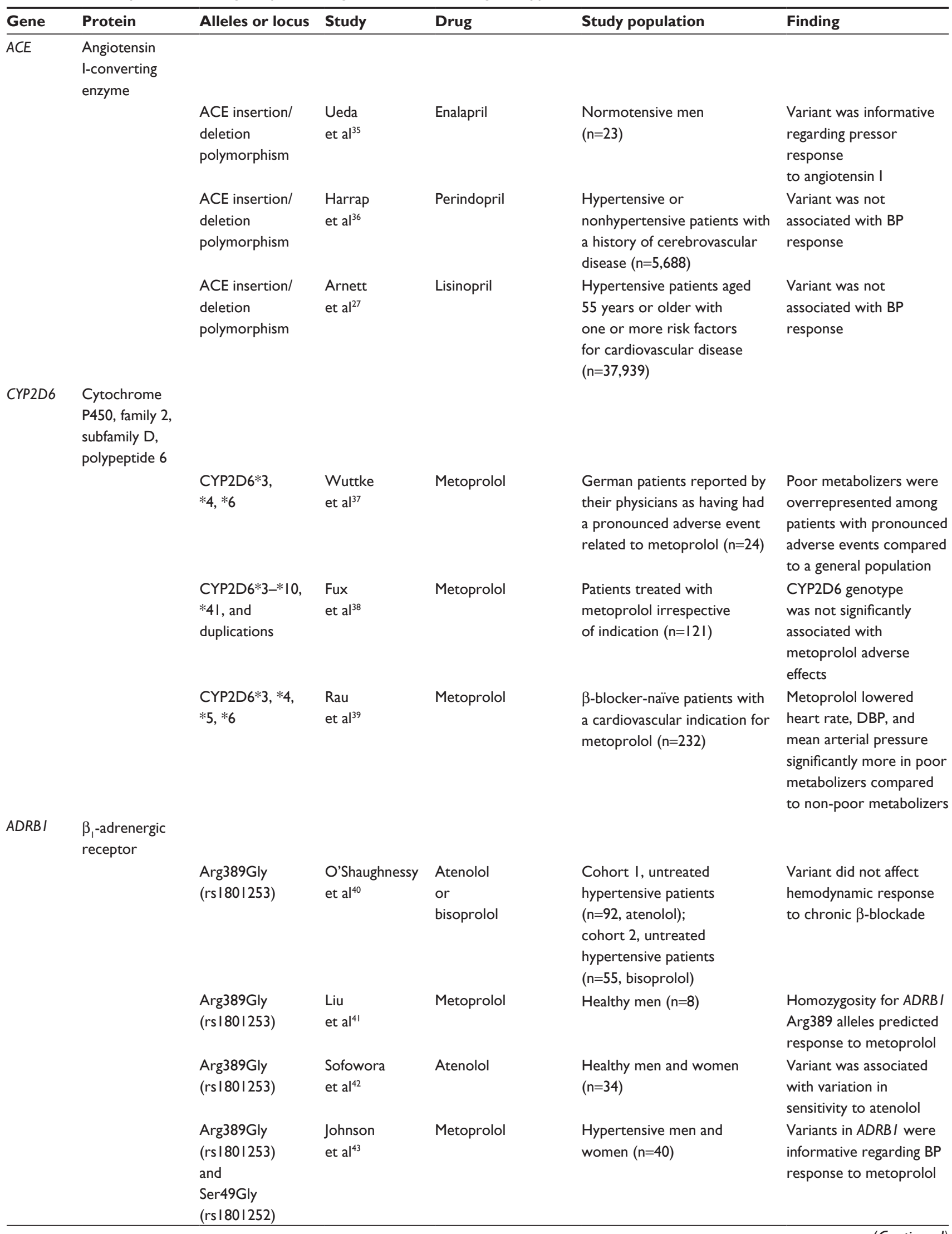


Table I (Contiuned)

\begin{tabular}{|c|c|c|c|c|c|c|}
\hline Gene & Protein & Alleles or locus & Study & Drug & Study population & Finding \\
\hline & & $\begin{array}{l}\text { Arg389Gly } \\
\text { (rs|80I253) } \\
\text { and } \\
\text { Ser49Gly } \\
\text { (rs|80I252) }\end{array}$ & $\begin{array}{l}\text { Karlsson } \\
\text { et } \mathrm{al}^{44}\end{array}$ & Atenolol & $\begin{array}{l}\text { Hypertensive patients with } \\
\text { left ventricular hypertrophy } \\
(n=101)\end{array}$ & $\begin{array}{l}\text { Variants did not exert } \\
\text { a major effect on BP } \\
\text { response to atenolol }\end{array}$ \\
\hline & & $\begin{array}{l}\text { Arg389Gly } \\
\text { (rs|80I253) } \\
\text { and } \\
\text { Ser49Gly } \\
\text { (rs|80I252) }\end{array}$ & $\begin{array}{l}\text { Liu } \\
\text { et } \mathrm{al}^{45}\end{array}$ & Metoprolol & $\begin{array}{l}\text { Men and women with } \\
\text { essential hypertension }(n=6 I)\end{array}$ & $\begin{array}{l}\text { Variants in } A D R B I \text { were } \\
\text { informative regarding } B P \\
\text { response to metoprolol }\end{array}$ \\
\hline & & $\begin{array}{l}\text { Arg389Gly } \\
\text { (rs|80I253) } \\
\text { and } \\
\text { Ser49Gly } \\
\text { (rs|80I252) }\end{array}$ & $\begin{array}{l}\text { Kumar } \\
\text { et a }{ }^{46}\end{array}$ & Metoprolol & Healthy males $(n=4 I)$ & $\begin{array}{l}\text { Variants did not exert an } \\
\text { effect on BP response to } \\
\text { exercise during treatment } \\
\text { with metoprolol }\end{array}$ \\
\hline & & $\begin{array}{l}\text { Arg389Gly } \\
\text { (rs|80I253) } \\
\text { and } \\
\text { Ser49Gly } \\
\text { (rs|80I252) }\end{array}$ & $\begin{array}{l}\text { Suonsyrjä } \\
\text { et } \mathrm{al}^{47}\end{array}$ & Bisoprolol & $\begin{array}{l}\text { Moderately hypertensive men } \\
(\mathrm{n}=233)\end{array}$ & $\begin{array}{l}\text { Variants did not exert } \\
\text { a major effect on BP } \\
\text { response to bisoprolol }\end{array}$ \\
\hline & & $\begin{array}{l}\text { Arg389Gly } \\
\text { (rsI80I253) } \\
\text { and } \\
\text { Ser49Gly } \\
\text { (rs|80I252) }\end{array}$ & $\begin{array}{l}\text { Filigheddu } \\
\text { et } \mathrm{al}^{48}\end{array}$ & Atenolol & $\begin{array}{l}\text { Never-treated essential } \\
\text { hypertension patients }(n=340)\end{array}$ & $\begin{array}{l}\text { Variants did not exert an } \\
\text { effect on BP response to } \\
\text { atenolol }\end{array}$ \\
\hline \multirow[t]{4}{*}{ ADRB2 } & $\begin{array}{l}\beta_{2} \text {-adrenergic } \\
\text { receptor }\end{array}$ & & & & & \\
\hline & & $\begin{array}{l}\text { Gly|6Arg } \\
\text { (rs|0427|3) }\end{array}$ & $\begin{array}{l}\text { Suonsyrjä } \\
\text { et } \mathrm{al}^{47}\end{array}$ & Bisoprolol & $\begin{array}{l}\text { Moderately hypertensive men } \\
(\mathrm{n}=233)\end{array}$ & $\begin{array}{l}\text { Variants did not exert an } \\
\text { effect on BP response to } \\
\text { bisoprolol }\end{array}$ \\
\hline & & $\begin{array}{l}\text { Cys 19Arg } \\
\text { (rsI0427II), } \\
\text { Gly|6Arg } \\
\text { (rs|0427|3), } \\
\text { and } \\
\text { Gln27Glu } \\
\text { (rs|0427|4) }\end{array}$ & $\begin{array}{l}\text { Filigheddu } \\
\text { et al }{ }^{48}\end{array}$ & Atenolol & $\begin{array}{l}\text { Never-treated essential } \\
\text { hypertension patients }(n=340)\end{array}$ & $\begin{array}{l}\text { Variants did not exert an } \\
\text { effect on BP response to } \\
\text { atenolol }\end{array}$ \\
\hline & & rs2053044 & $\begin{array}{l}\text { Anthony } \\
\text { et } \mathrm{al}^{49}\end{array}$ & Ramipril & $\begin{array}{l}\text { Participants in the African } \\
\text { American Study of Kidney } \\
\text { Disease }(n=336)\end{array}$ & $\begin{array}{l}\text { Variant was associated } \\
\text { with time to BP control } \\
\text { assessed by mean arterial } \\
\text { pressure }\end{array}$ \\
\hline \multirow[t]{2}{*}{ GRK4 } & $\begin{array}{l}\text { G protein- } \\
\text { coupled } \\
\text { receptor } \\
\text { kinase } 4\end{array}$ & & & & & \\
\hline & & $\begin{array}{l}\text { Arg65Leu } \\
\text { (rs2960306), } \\
\text { Alal42Val } \\
\text { (rs|024323), } \\
\text { and } \\
\text { Ala486Val } \\
\text { (rs|80I058) }\end{array}$ & Vandell et al ${ }^{50}$ & $\begin{array}{l}\text { Atenolol } \\
\text { Candesartan, }\end{array}$ & $\begin{array}{l}\text { Patients with mild-to- } \\
\text { moderate hypertension } \\
(\mathrm{n}=768)\end{array}$ & $\begin{array}{l}\text { A variant diplotype was } \\
\text { associated with DBP } \\
\text { lowering during exposure } \\
\text { to atenolol }\end{array}$ \\
\hline
\end{tabular}


Table I (Contiuned)

\begin{tabular}{|c|c|c|c|c|c|c|}
\hline Gene & Protein & Alleles or locus & Study & Drug & Study population & Finding \\
\hline & & $\begin{array}{l}\text { Arg65Leu } \\
\text { (rs2960306), } \\
\text { Ala|42Val } \\
\text { (rs|024323), } \\
\text { and } \\
\text { Ala486Val } \\
\text { (rs|80I058) }\end{array}$ & Sanada et $\mathrm{a}^{51}$ & $\begin{array}{l}\text { Losartan, } \\
\text { telmisartan, or } \\
\text { valsartan }\end{array}$ & $\begin{array}{l}\text { Patients with essential } \\
\text { hypertension }(n=829)\end{array}$ & $\begin{array}{l}\text { The } I 42 \mathrm{~V} \text { allele was } \\
\text { informative regarding } \\
\text { decrease in SBP during } \\
\text { exposure to ARBs }\end{array}$ \\
\hline \multirow[t]{4}{*}{ NEDD4L } & $\begin{array}{l}\text { Neural } \\
\text { precursor cell } \\
\text { expressed, } \\
\text { developmentally } \\
\text { downregulated } \\
\text { 4-like, E3 } \\
\text { ubiquitin } \\
\text { protein ligase }\end{array}$ & & & & & \\
\hline & & rs4l4960l & Luo et $\mathrm{al}^{52}$ & Hydrochlorothiazide & $\begin{array}{l}\text { Patients with hypertension } \\
\text { ( } n=833 \text { ) compared to normal } \\
\text { controls ( } n=853 \text {, case-control } \\
\text { study) }\end{array}$ & $\begin{array}{l}\text { Allele was associated } \\
\text { with BP response to } \\
\text { hydrochlorothiazide }\end{array}$ \\
\hline & & rs4l4960l & $\begin{array}{l}\text { Svensson- } \\
\text { Färbom et al }{ }^{53}\end{array}$ & $\begin{array}{l}\text { A thiazide diuretic } \\
\text { or } \beta \text {-blocker }\end{array}$ & $\begin{array}{l}\text { Patients with hypertension } \\
(\mathrm{DBP}>100 \mathrm{mmHg}, \mathrm{n}=\mathrm{I}, 863)\end{array}$ & $\begin{array}{l}\text { In patients treated with } \\
\beta \text {-blocker or diuretic } \\
\text { monotherapy, allele } \\
\text { associated with SBP and } \\
\text { DBP reduction }\end{array}$ \\
\hline & & $\begin{array}{l}\text { rs } 414960 I, \\
\text { rs } 292449, \\
\text { rs1008899, and } \\
\text { rs759828I3 }\end{array}$ & $\begin{array}{l}\text { McDonough } \\
\text { et al }{ }^{54}\end{array}$ & Hydrochlorothiazide & $\begin{array}{l}\text { Patients with-mild-to } \\
\text { moderate hypertension } \\
(n=768)\end{array}$ & $\begin{array}{l}\text { Significant associations } \\
\text { or trends were found } \\
\text { between each of the four } \\
\text { variants and response to } \\
\text { hydrochlorothiazide in } \\
\text { whites; no associations } \\
\text { were found with respect } \\
\text { to response to atenolol }\end{array}$ \\
\hline
\end{tabular}

Abbreviations: $B P$, blood pressure; $D B P$, diastolic $B P ; S B P$, systolic $B P ; A R B s$, angiotensin-receptor blockers.

\section{Genome-wide association approach to pharmacogenomics}

There are reasons to doubt whether the DNA sequence can powerfully predict response to antihypertensive drugs. Specifically, the invariant nature of the DNA sequence means that environmental influences on BP response are not accounted for by sequence analysis. The GENRES randomized, placebocontrolled, crossover trial was published earlier this year. ${ }^{29}$ The study was informed by a genome-wide association study, and suggested a possible relationship between nephrosis (NPNS1) gene variants and response to an angiotensinreceptor antagonist - losartan. In addition, evidence was found supporting two other genes' (ALDH1A3 and CLIC5) influence on BP response to hydrochlorothiazide.

\section{Hemodynamic assessments}

Arterial stiffness has been proposed as a parameter that might permit personalized selection of antihypertensive medications. Protogerou et al analyzed arterial stiffness by pulse-wave velocity in a randomized, double-blind, clinical trial comparing atenolol to perindopril/indapamide. They found that baseline pulse-wave velocity predicted response to antihypertensive medication. ${ }^{30}$

\section{Personalized medicine and current hypertension guidelines}

To the extent that guideline-based treatment of hypertension has been personalized in the US, it has been on the basis of phenotypes perceived as requiring no testing (eg, race) and phenotypes requiring simple diagnostic testing (eg, chronic kidney disease and diabetes). The most recent Joint National Committee (JNC) discussion of routine diagnostic testing in hypertension was published just 2 years after the human genome was decoded. ${ }^{31}$ JNC 7 recommended a modest degree of personalization, using methods more than 40 years old (12-lead electrocardiography, urinalysis, blood glucose, 
hematocrit, serum potassium, creatinine, calcium, fasting lipoprotein profile). In contrast, the document written by the JNC 8 committee did not offer an update regarding diagnostic testing, although its recommendations assume a knowledge of whether the patient has chronic kidney disease or diabetes. ${ }^{32}$ The European Society of Hypertension guidelines suggest that laboratory investigation of hypertension proceed from "the most simple to more complicated ones". ${ }^{33}$ In summary, current hypertension guidelines emphasize simplicity and pragmatism in diagnostic testing.

\section{Emerging approaches to personalized medicine in the treatment of hypertension}

Future approaches to the personalization of hypertension treatment will likely focus less on the DNA sequence and more on variables that can change over time. The DNA sequence is static throughout life, but the emergent effect of the DNA sequence and the environment on BP is dynamic, changing throughout life. Looking further downstream from the DNA at quantifiable, emergent determinants of BP and drug response will likely prove more useful. For example, Qi et al recently showed a relationship between activation of the renin-angiotensin-aldosterone system (RAAS) or exogenous administration of aldosterone and the presence of subunits of the epithelial sodium channel in urinary extracellular vesicles. ${ }^{34}$ Therefore, a new means of evaluating the RAAS may have arrived, and with it a host of questions that were intractable in the past. Whether these extracellular vesicles are participating in a new form of endocrine signaling is unknown, and is an area of intense investigation. Moreover, we are witnessing the emergence of clinical "-omics" approaches that will reflect physiological states influenced by the environment, rather than static genomic information. The fields of epigenomics, metabolomics, proteomics, transcriptomics, and lipidomics are likely to yield data useful in personalizing treatment of hypertension.

\section{Conclusion}

No approach to the personalization of hypertension therapy has been demonstrated to have unequivocal value, yet spectacular recent advances in the ability to measure human physiology open a window of opportunity to move beyond the current state of affairs toward personalized medicine in hypertension. Personalized therapy for hypertension appears to be in its infancy. Because of the clear promise of improved health if progress is made, the NIH and FDA have devoted significant resources to fostering personalized medicine. Additional government investment in personalized hypertension care appears well justified in view of hypertension's prime role in deaths and disability around the globe compounded by well-known medication-intolerance issues leading to poor adherence. The field of hypertension awaits the development of clinically feasible phenotyping methods that allow clinicians to draw strong inferences about pathophysiology.

\section{Disclosure}

The author reports no conflicts of interest in this work.

\section{References}

1. Lim SS, Vos T, Flaxman AD, et al. A comparative risk assessment of burden of disease and injury attributable to 67 risk factors and risk factor clusters in 21 regions, 1990-2010: a systematic analysis for the Global Burden of Disease Study 2010. Lancet. 2012;380(9859):2224-2260.

2. Hamburg MA, Collins FS. The path to personalized medicine. $N$ Engl JMed. 2010;363(4):301-304.

3. Turner ST, Schwartz GL, Boerwinkle E. Personalized medicine for high blood pressure. Hypertension. 2007;50(1):1-5.

4. Byrd JB, Touzin K, Sile S, et al. Dipeptidyl peptidase IV in angiotensinconverting enzyme inhibitor associated angioedema. Hypertension. 2008;51(1):141-147.

5. Mazzaglia G, Ambrosioni E, Alacqua M, et al. Adherence to antihypertensive medications and cardiovascular morbidity among newly diagnosed hypertensive patients. Circulation. 2009;120(16):1598-1605.

6. Tomaszewski M, White C, Patel P, et al. High rates of non-adherence to antihypertensive treatment revealed by high-performance liquid chromatography-tandem mass spectrometry (HP LC-MS/MS) urine analysis. Heart. 2014;100(11):855-861.

7. Jung $\mathrm{O}$, Gechter JL, Wunder C, et al. Resistant hypertension? Assessment of adherence by toxicological urine analysis. $J$ Hypertens. 2013;31(4):766-774.

8. Woodcock J. Assessing the clinical utility of diagnostics used in drug therapy. Clin Pharmacol Ther. 2010;88(6):765-773.

9. Karapetis CS, Khambata-Ford S, Jonker DJ, et al. K-ras mutations and benefit from cetuximab in advanced colorectal cancer. $N$ Engl J Med. 2008;359(17):1757-1765.

10. Verma S, Miles D, Gianni L, et al. Trastuzumab emtansine for HER2-positive advanced breast cancer. $N$ Engl J Med. 2012;367(19):1783-1791.

11. Scholl UI, Goh G, Stölting G, et al. Somatic and germline CACNA1D calcium channel mutations in aldosterone-producing adenomas and primary aldosteronism. Nat Genet. 2013;45(9):1050-1054.

12. Williams TA, Monticone S, Schack VR, et al. Somatic ATP1A1, ATP2B3, and KCNJ5 mutations in aldosterone-producing adenomas. Hypertension. 2014;63(1):188-195.

13. Law MR, Morris JK, Wald NJ. Use of blood pressure lowering drugs in the prevention of cardiovascular disease: meta-analysis of 147 randomised trials in the context of expectations from prospective epidemiological studies. BMJ. 2009;338:b1665.

14. Blake CM, Kharasch ED, Schwab M, Nagele P. A meta-analysis of CYP2D6 metabolizer phenotype and metoprolol pharmacokinetics. Clin Pharmacol Ther. 2013;94(3):394-399.

15. Shepherd AM, McNay JL, Ludden TM, Lin MS, Musgrave GE. Plasma concentration and acetylator phenotype determine response to oral hydralazine. Hypertension. 1981;3(5):580-585.

16. Tarazi RC, Frohlich ED, Dustan HP. Plasma volume in men with essential hypertension. N Engl J Med. 1968;278(14):762-765.

17. Harman RE, Ham EA, DeYoung JJ, Brink NG, Sarett LH. Isolation of aldosterone (electrocortin). J Am Chem Soc. 1954;76(20):5035-5036.

18. Conn JW. Presidential address. I. Painting background. II. Primary aldosteronism, a new clinical syndrome. J Lab Clin Med. 1955;45(1):3-17. 
19. Laragh JH, Ulick S, Januszewicz V, Deming QB, Kelly WG, Lieberman S. Aldosterone secretion and primary and malignant hypertension. J Clin Invest. 1960;39:1091-1106.

20. Mulatero P, Stowasser M, Loh KC, et al. Increased diagnosis of primary aldosteronism, including surgically correctable forms, in centers from five continents. J Clin Endocrinol Metab. 2004;89(3):1045-1050.

21. Laragh JH, Sealey JE. The plasma renin test reveals the contribution of body sodium-volume content $(\mathrm{V})$ and renin-angiotensin $(\mathrm{R})$ vasoconstriction to long-term blood pressure. Am J Hypertens. 2011;24(11):1164-1180.

22. Egan BM, Basile JN, Rehman SU, et al. Plasma renin test-guided drug treatment algorithm for correcting patients with treated but uncontrolled hypertension: a randomized controlled trial. Am J Hypertens. 2009;22(7):792-801.

23. Geller DS, Rodriguez-Soriano J, Vallo Boado A, et al. Mutations in the mineralocorticoid receptor gene cause autosomal dominant pseudohypoaldosteronism type I. Nat Genet. 1998;19(3):279-281.

24. Geller DS, Farhi A, Pinkerton N, et al. Activating mineralocorticoid receptor mutation in hypertension exacerbated by pregnancy. Science. 2000;289(5476):119-123.

25. Geller DS, Zhang J, Zennaro MC, et al. Autosomal dominant pseudohypoaldosteronism type 1: mechanisms, evidence for neonatal lethality, and phenotypic expression in adults. J Am Soc Nephrol. 2006;17(5):1429-1436.

26. Geller DS, Zhang J, Wisgerhof MV, Shackleton C, Kashgarian M, Lifton RP. A novel form of human Mendelian hypertension featuring nonglucocorticoid-remediable aldosteronism. J Clin Endocrinol Metab. 2008;93(8):3117-3123.

27. Arnett DK, Davis BR, Ford CE, et al. Pharmacogenetic association of the angiotensin-converting enzyme insertion/deletion polymorphism on blood pressure and cardiovascular risk in relation to antihypertensive treatment: the Genetics of Hypertension-Associated Treatment (GenHAT) study. Circulation. 2005;111(25):3374-3383.

28. Ioannidis JP, Ntzani EE, Trikalinos TA, Contopoulos-Ioannidis DG. Replication validity of genetic association studies. Nat Genet. 2001;29(3):306-309.

29. Hiltunen TP, Donner KM, Sarin AP, et al. Pharmacogenomics of hypertension: a genome-wide, placebo-controlled cross-over study, using four classes of antihypertensive drugs. $J$ Am Heart Assoc. 2015;4(1):e001521.

30. Protogerou A, Blacher J, Stergiou GS, Achimastos A, Safar ME. Blood pressure response under chronic antihypertensive drug therapy: the role of aortic stiffness in the REASON (Preterax in Regression of Arterial Stiffness in a Controlled Double-Blind) study. J Am Coll Cardiol. 2009;53(5):445-451.

31. Chobanian AV, Bakris GL, Black HR, et al. Seventh report of the Joint National Committee on Prevention, Detection, Evaluation, and Treatment of High Blood Pressure. Hypertension. 2003;42(6):1206-1252.

32. James PA, Oparil S, Carter BL, et al. 2014 Evidence-based guideline for the management of high blood pressure in adults: report from the panel members appointed to the Eighth Joint National Committee (JNC 8). JAMA. 2014;311(5):507-520.

33. Mancia G, Fagard R, Narkiewicz K, et al. 2013 ESH/ESC guidelines for the management of arterial hypertension: the Task Force for the Management of Arterial Hypertension of the European Society of Hypertension (ESH) and of the European Society of Cardiology (ESC). J Hypertens. 2013;31(7):1281-1357.

34. Qi Y, Wang X, Rose KL, et al. Activation of the endogenous reninangiotensin-aldosterone system or aldosterone administration increases urinary exosomal sodium channel excretion. J Am Soc Nephrol. Epub 2015 Jun 25

35. Ueda S, Meredith PA, Morton JJ, Connell JM, Elliott HL. ACE (I/D) genotype as a predictor of the magnitude and duration of the response to an ACE inhibitor drug (enalaprilat) in humans. Circulation. 1998;98(20):2148-2153.
36. Harrap SB, Tzourio C, Cambien F, et al. The ACE gene I/D polymorphism is not associated with the blood pressure and cardiovascular benefits of ACE inhibition. Hypertension. 2003;42(3):297-303.

37. Wuttke H, Rau T, Heide R, et al. Increased frequency of cytochrome P450 2D6 poor metabolizers among patients with metoprolol-associated adverse effects. Clin Pharmacol Ther. 2002;72(4):429-437.

38. Fux R, Mörike K, Pröhmer AM, et al. Impact of CYP2D6 genotype on adverse effects during treatment with metoprolol: a prospective clinical study. Clin Pharmacol Ther. 2005;78(4):378-387.

39. Rau T, Wuttke H, Michels LM, et al. Impact of the CYP2D6 genotype on the clinical effects of metoprolol: a prospective longitudinal study. Clin Pharmacol Ther. 2009;85(3):269-272.

40. O'Shaughnessy KM, Fu B, Dickerson C, Thurston D, Brown MJ. The gain-of-function G389R variant of the $\beta 1$-adrenoceptor does not influence blood pressure or heart rate response to $\beta$-blockade in hypertensive subjects. Clin Sci (Lond). 2000;99(3):233-238.

41. Liu J, Liu ZQ, Tan ZR, et al. Gly389Arg polymorphism of $\beta 1$-adrenergic receptor is associated with the cardiovascular response to metoprolol. Clin Pharmacol Ther. 2003;74(4):372-379.

42. Sofowora GG, Dishy V, Muszkat M, et al. A common $\beta 1$-adrenergic receptor polymorphism (Arg389Gly) affects blood pressure response to $\beta$-blockade. Clin Pharmacol Ther. 2003;73(4):366-371.

43. Johnson JA, Zineh I, Puckett BJ, McGorray SP, Yarandi HN, Pauly DF. $\beta 1$-Adrenergic receptor polymorphisms and antihypertensive response to metoprolol. Clin Pharmacol Ther. 2003;74(1):44-52.

44. Karlsson J, Lind L, Hallberg P, et al. $\beta 1$-Adrenergic receptor gene polymorphisms and response to $\beta 1$-adrenergic receptor blockade in patients with essential hypertension. Clin Cardiol. 2004;27(6):347-350.

45. Liu J, Liu ZQ, Yu BN, et al. beta1-Adrenergic receptor polymorphisms influence the response to metoprolol monotherapy in patients with essential hypertension. Clin Pharmacol Ther. 2006;80(1):23-32.

46. Kumar KN, Ramu P, Rajan S, Shewade DG, Balachander J, Adithan C. Genetic polymorphisms of $\beta 1$ adrenergic receptor and their influence on the cardiovascular responses to metoprolol in a South Indian population. J Cardiovasc Pharmacol. 2008;52(5):459-466.

47. Suonsyrjä T, Donner K, Hannila-Handelberg T, Fodstad H, Kontula K, Hiltunen TP. Common genetic variation of $\beta 1$ - and $\beta 2$-adrenergic receptor and response to four classes of antihypertensive treatment. Pharmacogenet Genomics. 2010;20(5):342-345.

48. Filigheddu F, Argiolas G, Degortes S, et al. Haplotypes of the adrenergic system predict the blood pressure response to $\beta$-blockers in women with essential hypertension. Pharmacogenomics. 2010;11(3):319-325.

49. Anthony EG, Richard E, Lipkowitz MS, Bhatnagar V. Association of the ADRB2 (rs2053044) polymorphism and angiotensin-converting enzyme-inhibitor blood pressure response in the African American Study of Kidney Disease and Hypertension. Pharmacogenet Genomics. 2015;25(9):444-449.

50. Vandell AG, Lobmeyer MT, Gawronski BE, et al. G protein receptor kinase 4 polymorphisms: $\beta$-blocker pharmacogenetics and treatmentrelated outcomes in hypertension. Hypertension. 2012;60(4):957-964.

51. Sanada H, Yoneda M, Yatabe J, et al. Common variants of the G proteincoupled receptor type 4 are associated with human essential hypertension and predict the blood pressure response to angiotensin receptor blockade. Pharmacogenomics J. Epub 2015 Mar 3.

52. Luo F, Wang Y, Wang X, Sun K, Zhou X, Hui R. A functional variant of NEDD4L is associated with hypertension, antihypertensive response, and orthostatic hypotension. Hypertension. 2009;54(4):796-801.

53. Svensson-Färbom $P$, Wahlstrand $B$, Almgren $P$, et al. A functional variant of the NEDD4L gene is associated with beneficial treatment response with $\beta$-blockers and diuretics in hypertensive patients. $J$ Hypertens. 2011;29(2):388-395.

54. McDonough CW, Burbage SE, Duarte JD, et al. Association of variants in NEDD4L with blood pressure response and adverse cardiovascular outcomes in hypertensive patients treated with thiazide diuretics. J Hypertens. 2013;31(4):698-704. 
Integrated Blood Pressure Control

Dovepress

\section{Publish your work in this journal}

Integrated Blood Pressure Control is an international, peer-reviewed open-access journal focusing on the integrated approach to managing hypertension and risk reduction. Treating the patient and comorbidities together with diet and lifestyle modification and optimizing healthcare resources through a multidisciplinary team approach constitute key features of the journal. This journal is indexed on American Chemical Society's Chemical Abstracts Service (CAS). The manuscript management system is completely online and includes a very quick and fair peerreview system, which is all easy to use. Visit http://www.dovepress.com/ testimonials.php to read real quotes from published authors.

\footnotetext{
Submit your manuscript here: http://www.dovepress.com/integrated-blood-pressure-control-journal
} 